$\mathrm{DOE} / \mathrm{BC} / 14952-10$

Distribution Category UC-122

\title{
SECONDARY OIL RECOVERY FROM SELECTED CARTER SANDSTONE OILFIELDS--BLACK WARRIOR BASIN, ALABAMA
}

\section{FINAL REPORT}

By

James C. Anderson

February 1995

Work Performed Under Contract No. DE-FC22-93BC14952

Prepared for

U.S. Department of Energy

Assistant Secretary for Fossil Energy

\author{
Gene Pauling, Project Manager \\ Metairie Site Office \\ 900 Commerce Road, East \\ New Orleans, LA 70123
}

Prepared by

Anderman/Smith Operating Company

1776 Lincoln Street, Suite 500

Denver, CO 80203

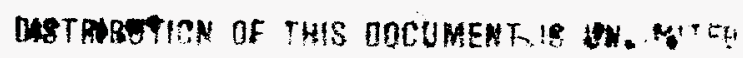
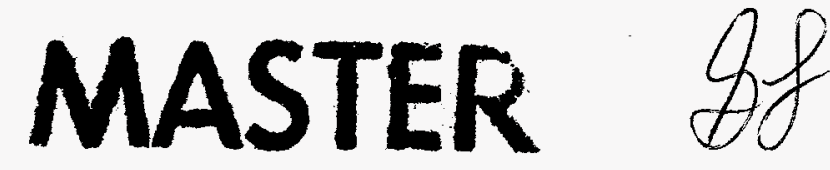


\section{DISCLAIMER}

This report was prepared as an account of work sponsored by an agency of the United States Government. Neither the United States Government nor any agency thereof, nor any of their employees, make any warranty, express or implied, or assumes any legal liability or responsibility for the accuracy, completeness, or usefulness of any information, apparatus, product, or process disclosed, or represents that its use would not infringe privately owned rights. Reference herein to any specific commercial product, process, or service by trade name, trademark, manufacturer, or otherwise does not necessarily constitute or imply its endorsement, recommendation, or favoring by the United States Government or any agency thereof. The views and opinions of authors expressed herein do not necessarily state or reflect those of the United States Government or any agency thereof. 


\section{DISCLAIMER}

Portions of this document may be illegible in electronic image products. Images are produced from the best available original document. 


\section{TABLE OF CONTENTS}

Page

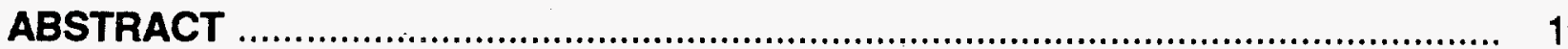

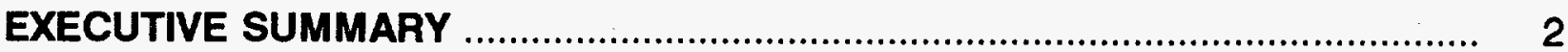

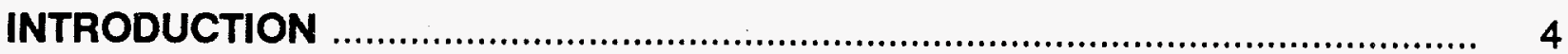

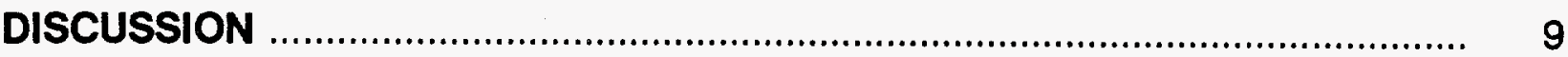

a. Central Bluff Unit ................................................................................

Field Operations Performed ................................................ 9

Waterflood Results ............................................................ 10

Reservoir Modeling ........................................................... 16

b. North Fairview Unit .................................................................... 21

Field Operations Performed .................................................... 21

Waterflood Results ................................................................. 22

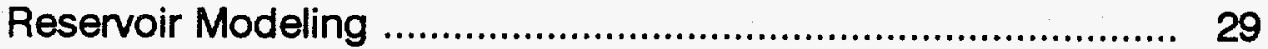




\section{LIST OF TABLES}

Table 1 Central Bluff Carter Oil Unit, Chronology of Events

Page

Table 2 Central Bluff Upper Carter Oil Unit, Monthly Operations Report...

Table 3 North Fairview Carter Oil Unit, Chronology of Events 21

Table 4 North Fairview Carter Oil Unit, Monthly Operations Report .... 23 


\section{LIST OF FIGURES}

Figure 1 Carter Sandstone Waterflood Location Map

Page

Figure 2 Bluff Area .......................................................................... 7

Figure $3 \quad$ North Fainiew Unit Isopach Map ............................................... 8

Figure 4 Oil Production, Central Bluff Unit ................................................... 12

Figure $5 \quad$ Water Injection, Jones 7-16, Central Bluff Unit ................................ 13

Figure 6 Production Rates, Fowler Brasher 7-9, Central Bluff Unit .................. 14

Figure 7 Production Rates, Fowler Dodson 8-12, Central Bluff Unit ................. 15

Figure 8 Central Bluff Oil Production, History Match .................................... 18

Figure 9 Central Bluff Gas Production, History Match ..................................... 19

Figure 10 Central Bluff Water Production, History Match .................................... 20

Figure 11 Oil Production, North Fairview Unit f.............................................. 24

Figure 12 Water Injection, North Fairview Unit f............................................... 25

Figure 13 Production Rates, Smith 33-6, North Fairview Unit .......................... 26

Figure 14 Production Rates, Perkins 33-11, North Fairview Unit ........................ 27

Figure 15 Production Rates, Perkins-Young 33-11, North Fairview Unit ............. 28

Figure $16 \quad$ North Fairview Oil Production, History Match ................................. 31

Figure 17 North Fairview Gas Production, History Match ................................. 32 


\section{ATTACHMENTS}

\section{Page}

DOE F1332.2 33,34

DOE F1332.3, Central Bluff 35

DOE F1332.3, No. Fairview

DOE F1332.3, So. Bluff

SF 269 Financial Status Report 


\section{ABSTRACT}

In this Class I PON, Anderman/Smith Operating Company targeted three Carter sandstone oilfields (Black Warrior Basin) for secondary recovery. Waterfloods are currently underway in two of the areas - Central Bluff and North Fairview units. For the third area, South Bluff, unitization efforts have been suspended and will not be addressed in this final report. 


\section{EXECUTIVE SUMMARY}

Anderman/Smith Operating Company initiated a secondary recovery project involving two Carter sandstone oilfields located in the Black Warrior Basin of northwest Alabama. These are the Central Bluff and North Fairview fields. Producibility problems, such as low reservoir pressure and reservoir heterogeneity, have severely limited oil production from these fields. It is believed that detailed geologic and engineering studies combined with conventional waterflood technologies will overcome many of these producibility problems and demonstrate the viability of secondary recovery in small depleted reservoirs. Specific objectives for this project were:

1. To successfully apply detailed geologic and engineering studies with conventional waterflood technologies to these fields in an effort to increase the ultimate economic recovery of oil from Carter sandstone fields.

2. To extensively model, test and evaluate these technologies; thereby, developing a sound methodology for their use and optimization.

3. To team with Advanced Resources International and the United States Department of Energy to assimilate and transfer the information and results gathered from this study to other oil companies to encourage the widespread use of these technologies.

At Central Bluff, water injection facilities were constructed and water injection into one well began in January 1993. Oil response from the waterflood has been observed at both producing wells. One of the producing wells has experienced early water breakthrough and a concomitant drop in secondary oil rate. A reservoir modeling study was initiated to help develop an appropriate operating strategy for Central Bluff.

For the North Fairview unit waterflood, a previously abandoned well was converted 
for water injection which began in late June 1993. The reservoir is being re-pressurized, and unit water production has remained nil since flood start indicating the possible formation of an oil bank. A reservoir simulation to characterize the Carter sand at North Fairview was undertaken and the modeling results were used to forecast field performance.

Anderman/Smith applied and received approval for an extension of the Project Phase I budget period from September 30, 1993 to June 30, 1994. During this time period, an intensive study was performed on these two projects regarding operations, expenses, and ultimate economics.

The project was terminated due to unfavorable economics. The factors contributing to this decision were premature water breakthrough at Central Bluff, delayed flood response at North Fairview and stalled negotiations at the South Bluff site. 


\section{INTRODUCTION}

In the Carter sandstone, Black Warrior Basin, Alabama, oil production is constrained by low reservoir pressure and reservoir heterogeneity. Reservoir pressure is low due to previous oil and solution gas production. The reservoir heterogeneities result from the lenticular nature of the fluvial dominated deltaic sands.

Reservoir characteristics of the Carter sandstone in this area exhibit the following general trends:

* sand thicknesses range from 5 to 20 feet
* porosities vary from 9 to 22 percent, averaging 19 percent
* permeabilities are between 3 and 90 md, averaging 20 md
* water saturations are in the 14 to 30 percent range, with an average of 24
percent

The above reservoir characteristics are usually conducive to favorable producibility conditions. These oil resources can be further exploited through the use of competent reservoir engineering and geologic interpretation techniques. Techniques such as geophysical log correlations, cross-sectional and subsurface mapping of individual sand bodies, BHP pressure surveys, and reservoir modeling can be used to identify continuous sands with acceptable reservoir quality. Interpretation of the results from these methods can be used in the application of targeted waterflooding scenarios which can mitigate the effects of reservoir heterogeneities. In addition, waterflooding will restore a portion of the lost reservoir energy through repressurization.

Indeed, past experience in the Black Warrior Basin has demonstrated that Carter sandstone reservoirs respond favorably to secondary recovery techniques such as waterflooding. Primary production of reservoirs in this area has been approximately 5 to 10 percent OOIP, with secondary recovery methods resulting in production of another 
5 to 10 percent OOIP. Therefore, additional reserves, even in small reservoirs, can be economically recovered with a carefully designed secondary recovery program.

In this Class I program, Anderman/Smith Operating Company initiated waterfloods in two Carter Sandstone oilfields: Central Bluff and North Fairview. These fields are located near existing Carter waterfloods in Lamar and Fayette counties, Alabama (Figure 1).

The Central Bluff field is located in Sections 7 and 8, T14S, R13W, Fayette County (Figure 2). The field was discovered in 1984, and cumulative production as of December 1991 was approximately $71,000 \mathrm{bbl}$ oil and 175 MMCF gas. The field has structural relief of 30 feet defined by the three wells that delineate the field area. Sand thickness averages 8 feet, porosities 19 percent and initial water saturations 20 percent.

The North Fairview field is located in Section 33, T13S, R14W, Lamar County, (Figure 3). There are seven wells delineating the field area of approximately 150 acres. This field has produced 107,000 bbl oil and 100 MMCF gas from the Carter sandstone since its discovery in 1982. The field has structural relief of 30 feet, sand thickness averages 8 to 10 feet with porosities of 15 to 20 percent, and water saturations average 20 percent. 
Figure 1

\section{ANDERMAN/SMITH OPERATING COMPANY Waterflood Location Map}
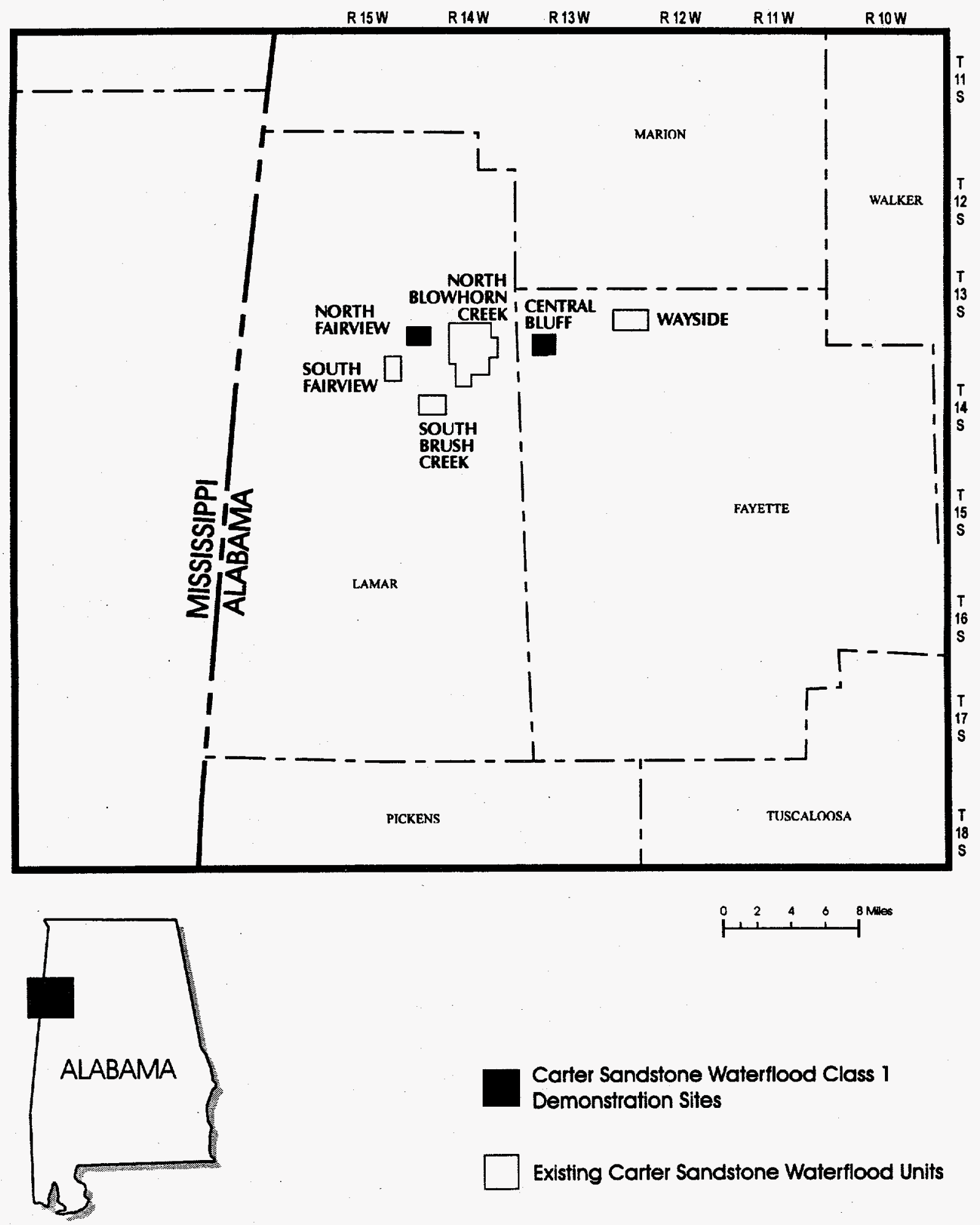

Carter Sandstone Waterflood Class 1

Demonstration Sites

Existing Carter Sandstone Waterflood Units 
Figure 2

\section{ANDERMAN/SMITH OPERATING COMPANY Bluff Area}

Fayette County, Alabama

\section{Carter Sandstone Isopach \\ $\varnothing_{D}>10 \%$}

A13W

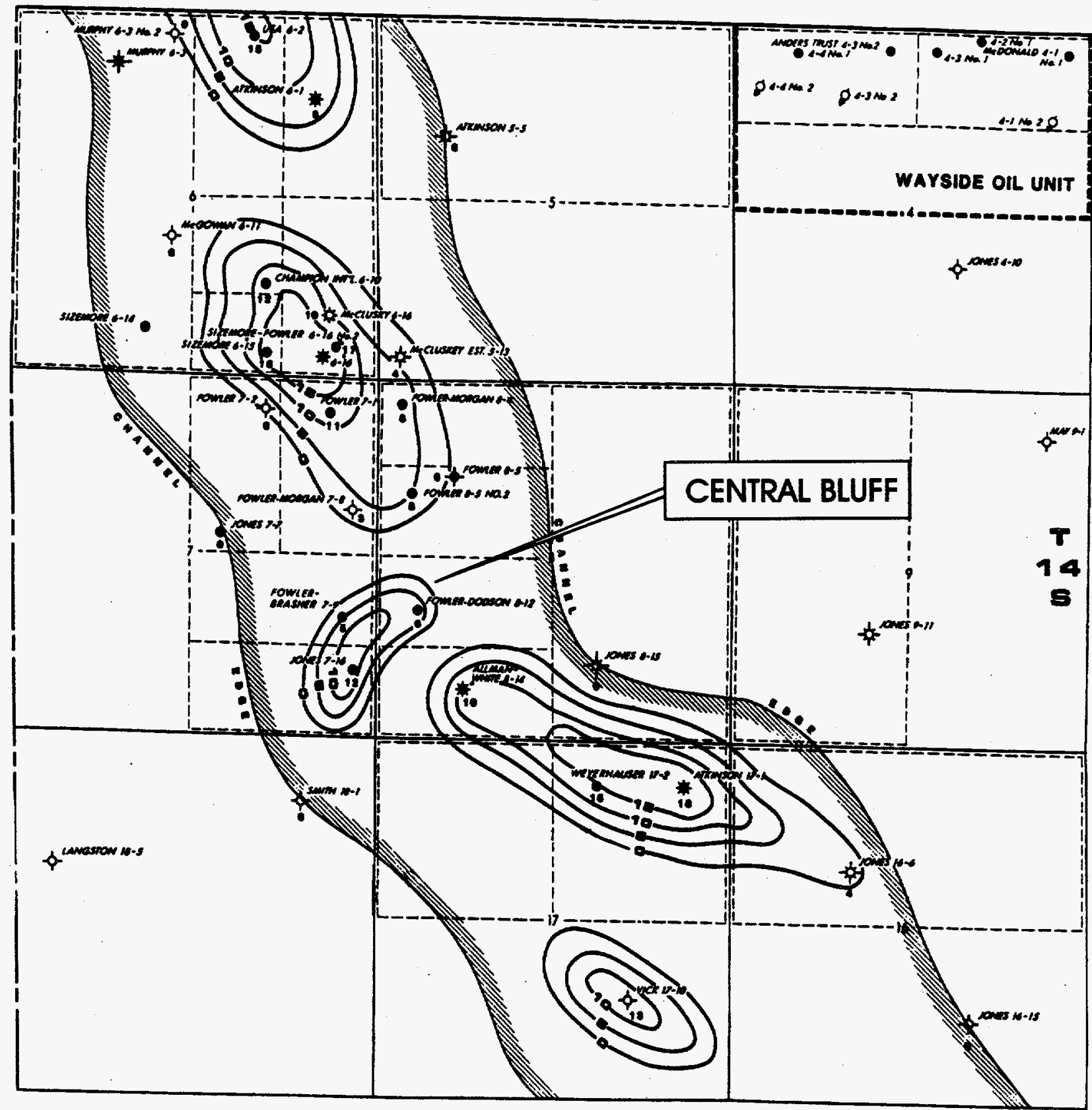

o $5001000 \quad 2000 \quad 3000$ feet 
Figure 3

\section{ANDERMAN/SMITH OPERATING COMPANY North Fairview Carter Oil Unit}

Lamar County, Alabama

Carter Sandstone Isopach

$$
\begin{aligned}
& \varnothing_{D}>10 \% \\
& \text { C.I. }=5 \text { feet }
\end{aligned}
$$

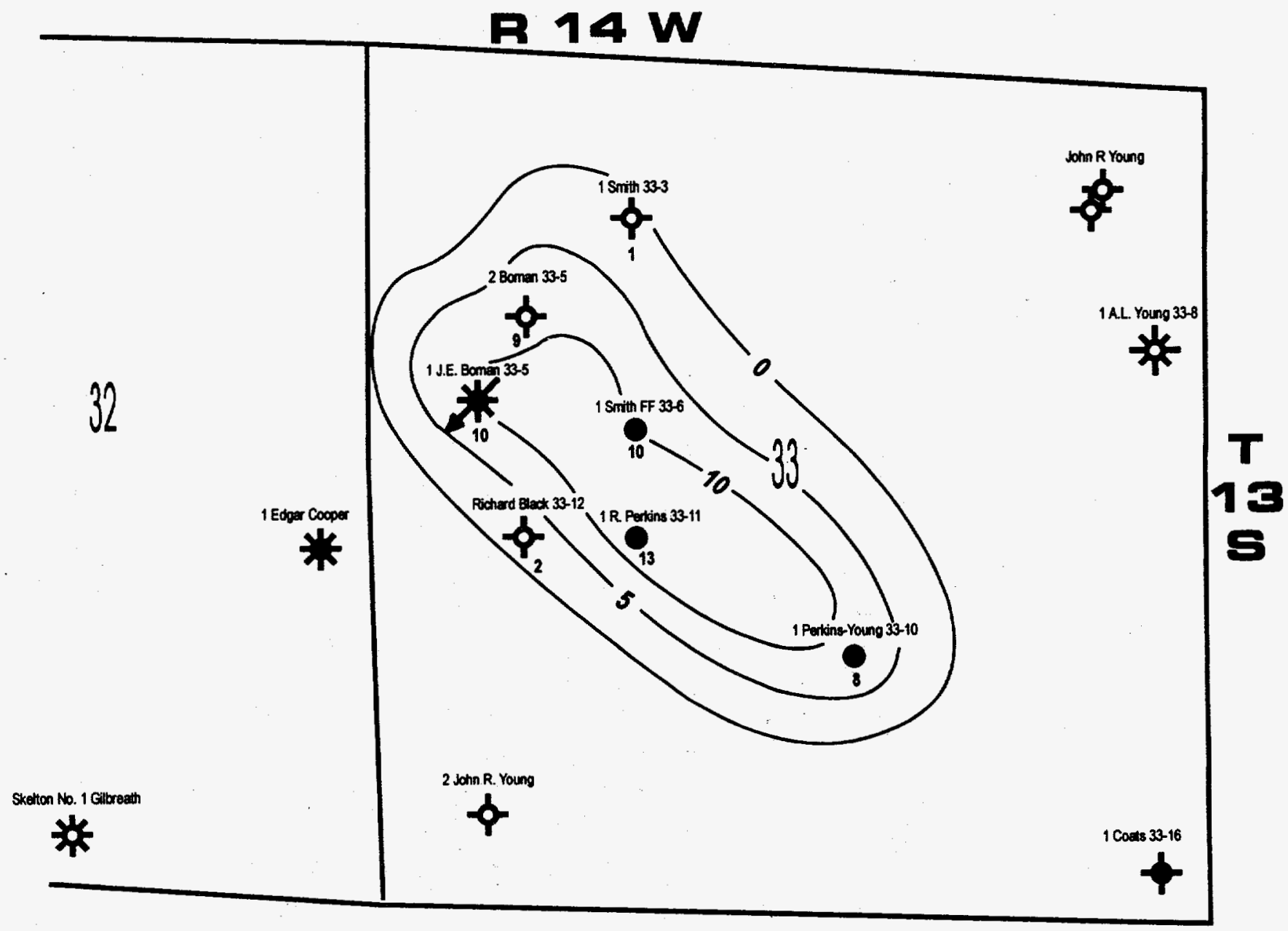




\section{DISCUSSION}

\section{a. Central Bluff Unit}

Field Operations Performed. Unitization for Central Bluff was approved on March 1, 1992. Activities prior and subsequent to the award of this DOE project in October 1992 are listed in Table 1. Activities during the period November 1992 - January 1993 involved construction of the water injection facilities.

\begin{tabular}{|c|c|}
\hline & $\begin{array}{c}\text { Table } 1 \\
\text { Central Blutf Carter Oil Unit } \\
\text { Chronology of Events }\end{array}$ \\
\hline Date & Description \\
\hline $03 / 01 / 92$ & Unit approved \\
\hline 05/12/92 & Sandblest and coat inside of injection tanks \\
\hline 08/24/92 & Workover Jones \#7-16 well \\
\hline $08 / 26 / 92$ & Clear timber for powerline ROW \\
\hline 08/26/92 & Order injection package \\
\hline $10 / 22-25 / 93$ & Clear ROW for powerlines \\
\hline $11 / 01 / 92$ & Start construction on location, slabs, etc. \\
\hline $1 \cdot 1 / 05 / 92$ & Stringing powerlines \\
\hline $11 / 14 / 92$ & Drill water source well \\
\hline $12 / 04-09 / 92$ & Install electrical panel \\
\hline $12 / 11 / 92$ & Construct building over injection package \\
\hline $12 / 14 / 92$ & Drop powerline to service pole \\
\hline $12 / 15 / 92$ & Mechanical integrity test with State O\&G representative \\
\hline $01 / 04 / 93$ & Gravel location \\
\hline $01 / 11 / 93$ & Refab suction line per pump manufacturer \\
\hline $01 / 12 / 93$ & Injection start-up and repair transformer \\
\hline $01 / 13 / 93$ & Monitor injection \\
\hline
\end{tabular}


In January 1993, the water source well (which was drilled in November 1992) was cleaned out. A mechanical integrity test was then run on this well and witnessed by a member of the Alabama Oil and Gas Board. During this period, a transformer on the REA powerline was repaired.

Start-up water injection into the Jones 7-16 well began on January 12, 1993. Pumps, flow lines and other facilities were checked after injection began. Daily operations began on January 13,1993 and have continued. These operations included monitoring wellhead pressures at the injection well and the two producing wells (Fowler Brasher 7-9 and Fowler Dodson 8-12), and treatment of the injection water.

Waterllood Results. A summary of the waterflood operations is given in Table 2 and Figures 4 thru 7. From injection start-up through September 1993, water injection rates averaged 200-250 BPD. However, no pressure buildup was observed during this period as the resenvoir took water on gravity. In late September 1993, the average water injection rate was increased to 300 BPD and the injection well began to pressure up, reaching 510 psi.

In early November, the injection rate was reduced to 250 BPD to stabilize the pressure at about 300-350 psi. In late November, a radioactive injection profile on the injection well showed that all but the upper 2 feet of perforations were covered with fill in the bottom of the hole. The well was cleaned out to about 60 feet below the perforations and water injection was subsequently resumed at an average rate between 250-275 BPD. These injection rates resulted in a rapid increase in the injection pressure from 250 to 560 psi for the Jones 7-16 well.

As a result of the water injection, an oil production increase was observed on October 15 at the Fowler Brasher 7-9 well (Figure 6). Oil production increased to 40-50 STBD in late October, and has averaged about 40 STBD through May 1994 with no measurable water production. 
Table 2

\section{CENTRAL BLUFF CARTER OIL UNIT \\ Monthly Operations Report}

UNITRED 3/V9R

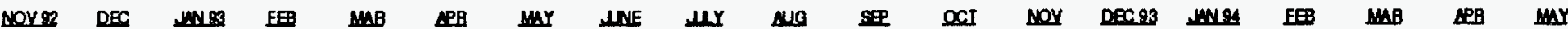

\begin{tabular}{|c|c|c|c|c|c|c|c|c|c|c|c|c|c|c|c|c|c|c|c|}
\hline Days on & 29 & 24 & 21 & 17 & 24 & 22 & 31 & 23 & 22 & 10. & 25 & so & 30 & 20 & 31 & 28 & 29 & 30 & 31 \\
\hline Monthly OII Production & 79 & 66 & 50 & 83 & 132 & 97 & 106 & 77 & 94 & 40 & 176 & 906 & 1,496 & 776 & 661 & 1,075 & 1,335 & 1,070 & 1,444 \\
\hline Daliy Avg. OA Production & 3 & 3 & 2 & 5 & 6 & 4 & 3 & 3 & 4 & 3. & 7 & 32 & 60 & 39 & 21 & 38 & 46 & 86 & 47 \\
\hline Cum. Oll Production & 72,219 & 72,243 & 72,293 & 72,376 & 72,508 & 72,605 & 72,711 & 72,788 & 72,882 & 72,922 & 73,098 & 74,064 & 75,559 & 76,335 & 76,996 & 78,071 & 79,406 & 80,476 & 81,920 \\
\hline Cum OllProd since Unitt & 800 & Bas & 919 & 100 & 1,134 & 1,231 & 1,337 & 1,414 & 1,500 & 1548 & 178 & 2,600 & 4,186 & 6001 & 5,022 & 6,697 & 8,000 & 9,10 & 10546 \\
\hline Monthly Gas Production & 179 & 165 & 180 & 100 & 195 & 145 & 355 & 115 & 115 & 52 & 241 & 19 & 0 & 0 & 0 & 0 & 0 & o & 0 \\
\hline Dally Avg Gas production. & 6. & 7 & 9 & 6 & 8 & 1 & 11 & 5 & 5 & 4 & to. & 1 & 0 & 0 & 야 & 0 & 0 & 0 & 0 \\
\hline Cum. Gas Production & 179,588 & 179,753 & 179,933 & 180,042 & 180,237 & 180,382 & 180,737 & 180,852 & 180,967 & 181,019 & 181,260 & 181,279 & 181,279 & 181,279 & 181,279 & 181,279 & 181,279 & 181,279 & 181,279 \\
\hline Cum aas Prod since unt & 2,190 & 2,364 & 2,54 & 2,050 & 2,648 & 2990 & 0,340 & 346 & 3.578 & 360 & 3871 & 3,890 & 3890 & $3 ; 090$ & 3090 & 3,890 & 3,000 & 3,890 & 0,890 \\
\hline GOP & 2,266 & 2,500 & 3,600 & 1,313 & $1,4 \pi$ & 1,496 & 3,349 & 1,494 & 1,223 & 1,300 & 1,360 & 20 & 0 & 0 & 0 & 0 & 0 & 0 & 0 \\
\hline Montily Water Production & 0 & 8 & 0 & 67 & 0 & 0 & 0 & 0 & 0 & 0 & 0 & 0 & 80 & 310 & 111 & 474 & 94 & 0 & 6 \\
\hline Dally Avg. Whater Production & 0 & 0 & 0 & 4 & 0 & 0 & 0 & 0 & 0 & 0 & 0 & 0 & 18 & 16 & 4 & 17 & 3 & 0 & 0 \\
\hline Cum nuer Production & 1,785 & 1,790 & 1,790 & 1,860 & 1,600 & 1,000 & 1,800 & 1,800 & 1060 & 1,800 & 1000 & 1,800 & 2300 & 2,706 & 2,817 & 3,291 & 3,35 & 3,306 & 3,391 \\
\hline Cum. Water Prod. since Unit & 0 & 8 & 8 & 75 & 75 & 75 & 75 & 75 & 75 & 75 & 75 & 75 & 611 & 921 & 1,032 & 1,506 & 1,600 & 1,600 & 1,606 \\
\hline Monthly weor infecton & 0 & 0 & 4,563 & 7775 & 8,420 & 4,351 & 5,481 & 4,742 & 6734 & 5,09 & 1709 & 8,520 & $5: 972$ & 7720 & 3,5 & 2,441 & 1,160 & 2,722 & 7,196 \\
\hline Average In. Press. & 0 & 0 & 0 & 0 & 0 & 0 & 0 & 0 & 0 & 0 & 0 & 334 & 259 & 194 & 198 & 33 & 247 & 91 & 232 \\
\hline Dally Avg. Whater Injection & of & 0 & 218 & 457 & 351 & 198 & 177 & 206 & 306 & 416 & 308 & 284 & 199 & 386 & 10 & 87 & 7,250 & 9,977 & 17,173 \\
\hline Gum vater ln s anco Unit & 0 & 0 & 4883 & 12,358 & 20778 & 25,129 & 30,610 & 35,052 & 42006 & 4719 & 55204 & 63724 & 09696 & 2,42 & 80,560 & 83021 & 174 & 0 & 0 \\
\hline Produding Wells & 0 & 0 & 2 & 2 & 2 & 2 & 2 & 2 & 2 & 2 & 2 & 2 & 2 & 2 & 2 & 2 & 2 & 2 & 2 \\
\hline Hractive Wells & 2 & 2 & 0 & 0 & o. & 0 & o. & 0 & 0 & 0 & 0 & 0 & 0 & 0 & al & 0 & 0 & 0 & 0 \\
\hline Irjection Wells & & 1 & 1 & 1 & 1 & 1 & 1 & 1 & 1 & 1 & 1 & 1 & 1 & 1 & 1 & 1 & 1 & 1 & 1 \\
\hline Whater souroo Wols & 0 & 0 & 1 & 1 & 1 & 1 & 1 & 1 & 1 & 1 & 1 & 1 & 1 & 1 & 1 & 1 & 81 & 1 & \\
\hline
\end{tabular}




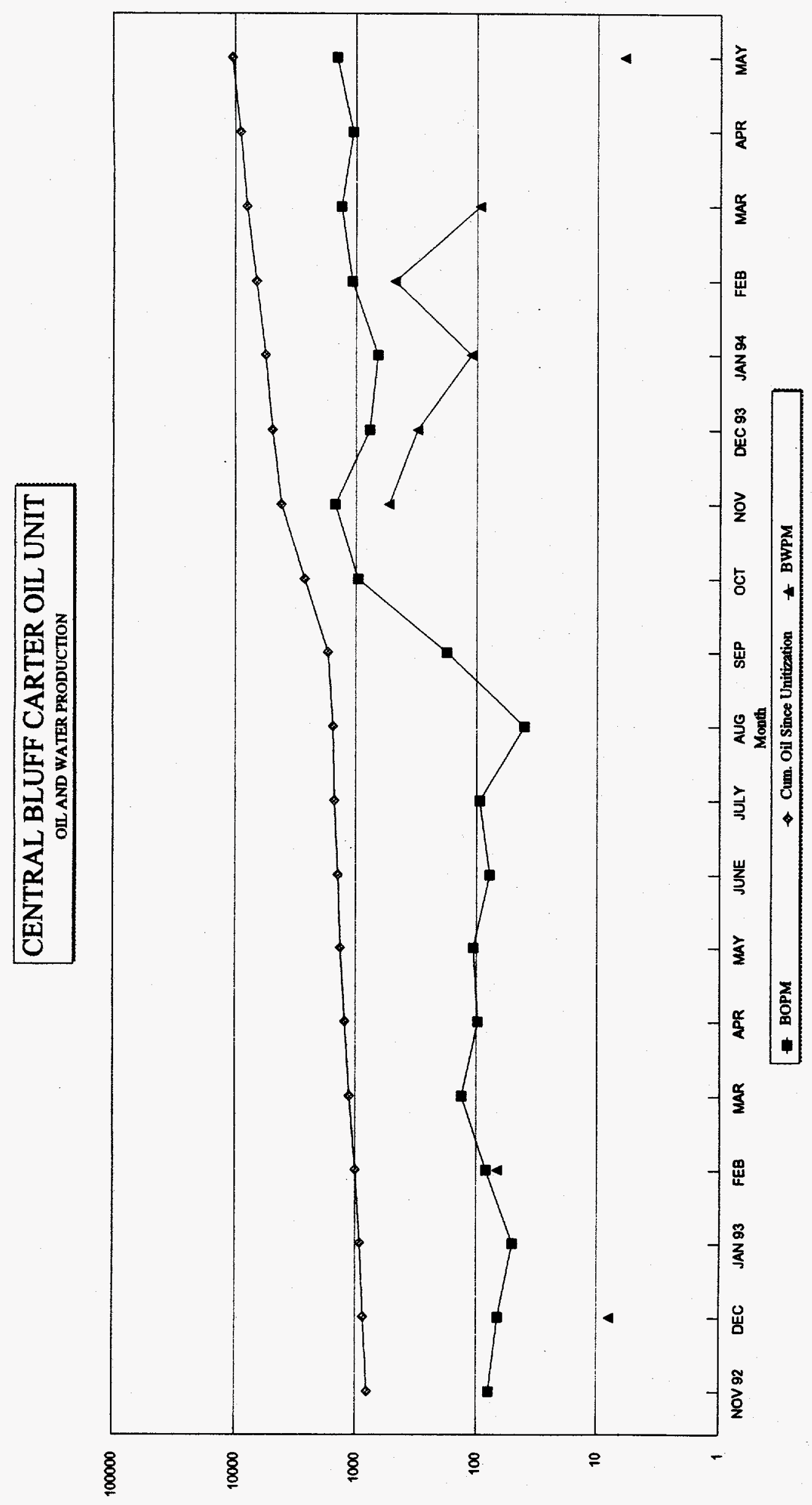

$\forall$
$\frac{0}{3}$
in 


\section{CENTRALBLUFF CARTER OIL UNIT}

Water Injection

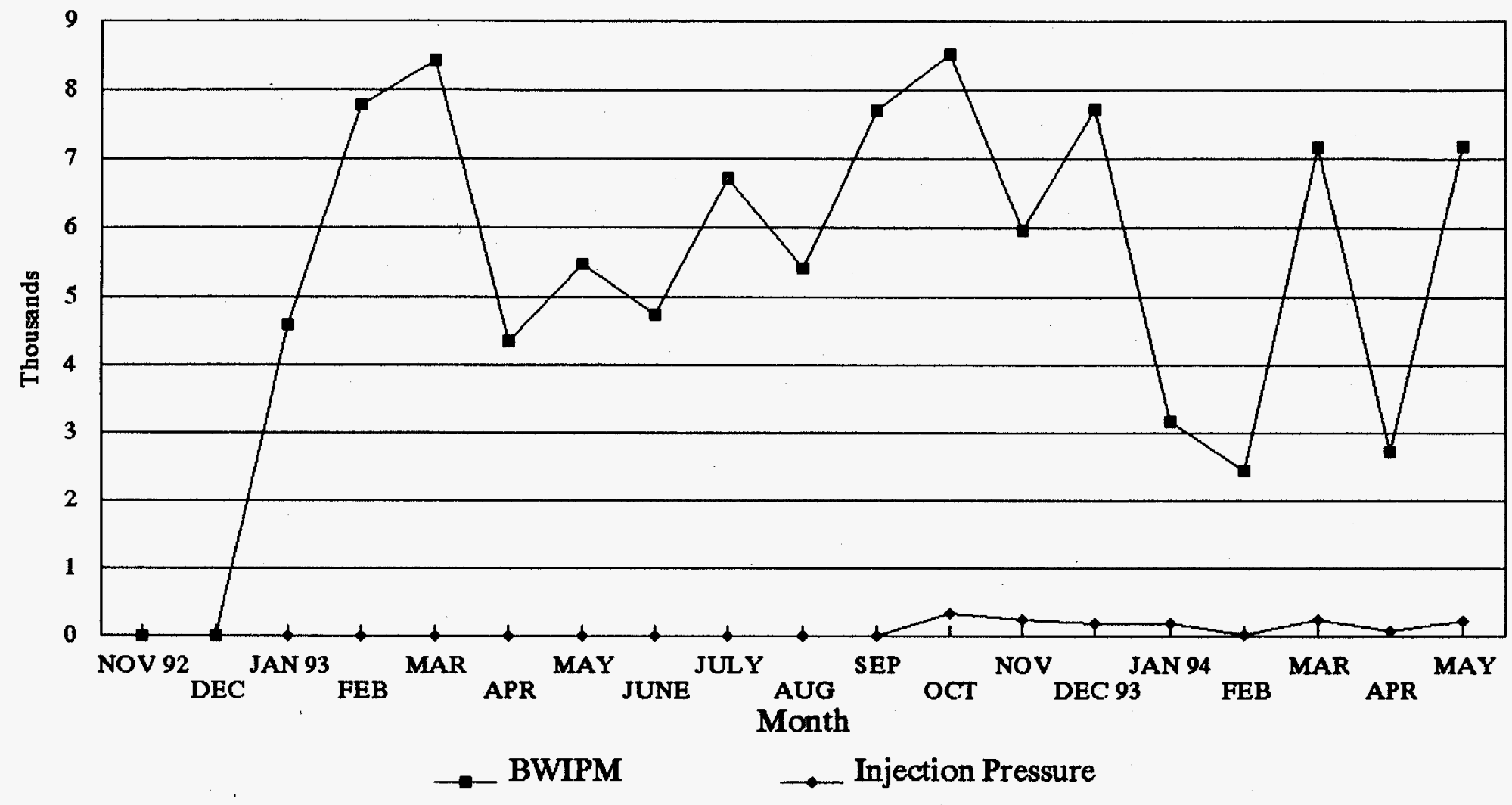

Figure 5 
Figure 6

\section{FOWLER BRASHER \#7-9 OIL PRODUCTION}

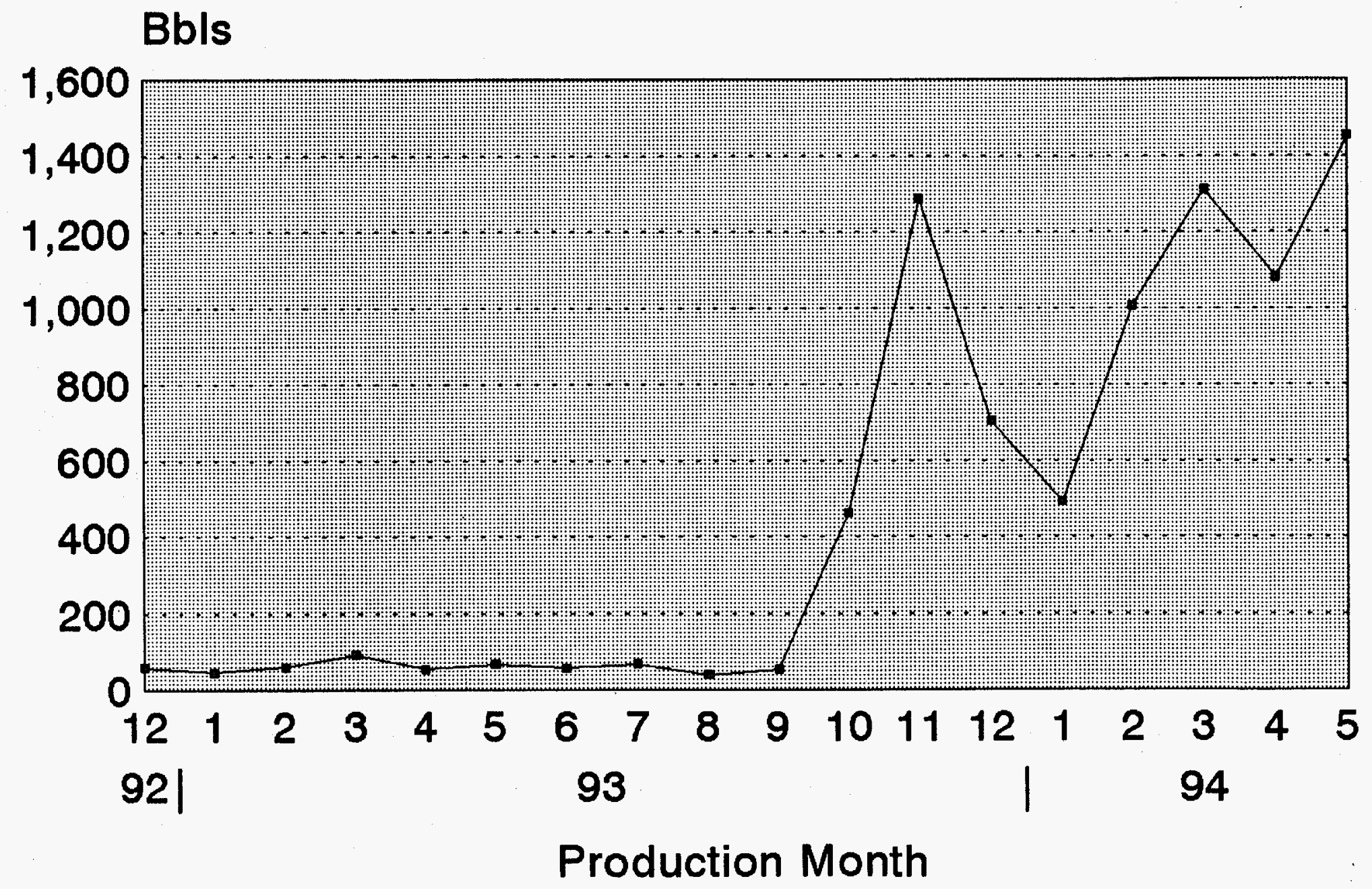

CENTRAL BLUFF CARTER OIL UNIT 


\section{FOWLER DODSON \#8-12 OIL PRODUCTION}

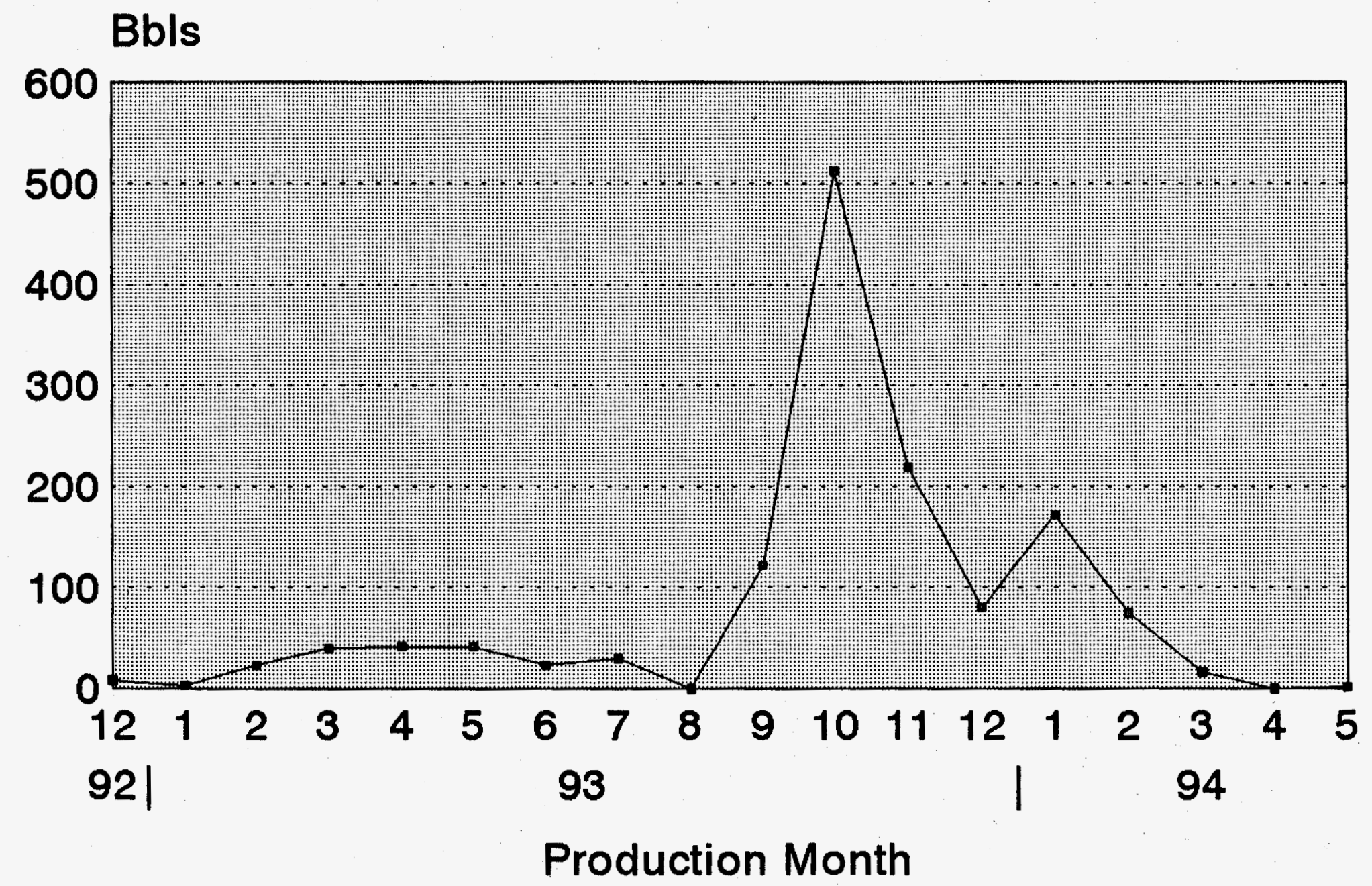

CENTRAL BLUFF CARTER OIL UNIT 
Production at the Fowler Dodson 8-12 was more erratic during the same period. An oil kick appeared in late September (Figure 7), and in October the average oil rate increased to nearly 17 STBD with no reported water production. However, in November, the oil production rate declined to about 9 STBD with an associated average water rate of nearly 17 BPD in the Fowler Dodson 8-12 well. Water analysis showed that this produced water was significantly fresher than the connate water produced prior to waterflood operations. This provided evidence for early breakthrough of water injected at the Jones 7-16 well.

Because of this earlier than expected water breakthrough at the Fowler-Dodson 8-12 location, several operating scenarios were evaluated. Sub-freezing temperatures in December through February forced the Jones 7-16 WIW to be shut-in. Pumping continued at the Fowler Dodson 8-12 with a continued increase in the water-oil ratio. Injection resumed in March and the Fowler Dodson well was shut-in. This well has remained shut-in pending our evaluation of a conversion to injection. Meanwhile, a 2" water line was laid to this well from the injection facilities.

In April, the water well sanded up and had to be cleaned out. Operations resumed and monitoring of the Fowler Brasher 7-9 has continued to date. There has been no indication of water at this location. $\mathrm{A} / \mathrm{SOC}$ is currently evaluating the conversion of the Fowler Dodson 8-12 in order to increase sweep efficiency in the field.

Reservoir Modeling. A reservoir modeling study of the Central Bluff Unit was initiated in November by Advanced Resources. The objectives of the study were to:

* Improve understanding of primary and secondary recovery

* Check/confirm no-flow boundaries

* Develop improved reservoir management scheme (e.g., optimal water injection strategy)

* Forecast oil recovery for various operating strategies 
Based on Anderman/Smith's revised geologic evaluation of the unit area, structure and net pay isopach maps were prepared for the Carter C2 sandstone. A $25 \times 28 \times 1$ reservoir simulation grid was constructed to cover an area of about 7,250 x 8,000 ft. A transparency of the grid was overlaid on the structure and isopach maps so that values of elevation and thickness could be digitized at grid block centers for input to the simulator.

Production and pressure data for the two producing wells and the injection well were history matched using the ROAST II simulator, a version of BOAST. Because no pressure transient testing was performed on the Central Bluff wells from which to estimate reservoir permeability, this and other parameters for which no data are available were estimated from matching actual field performance (Figures 8 thru 10). 


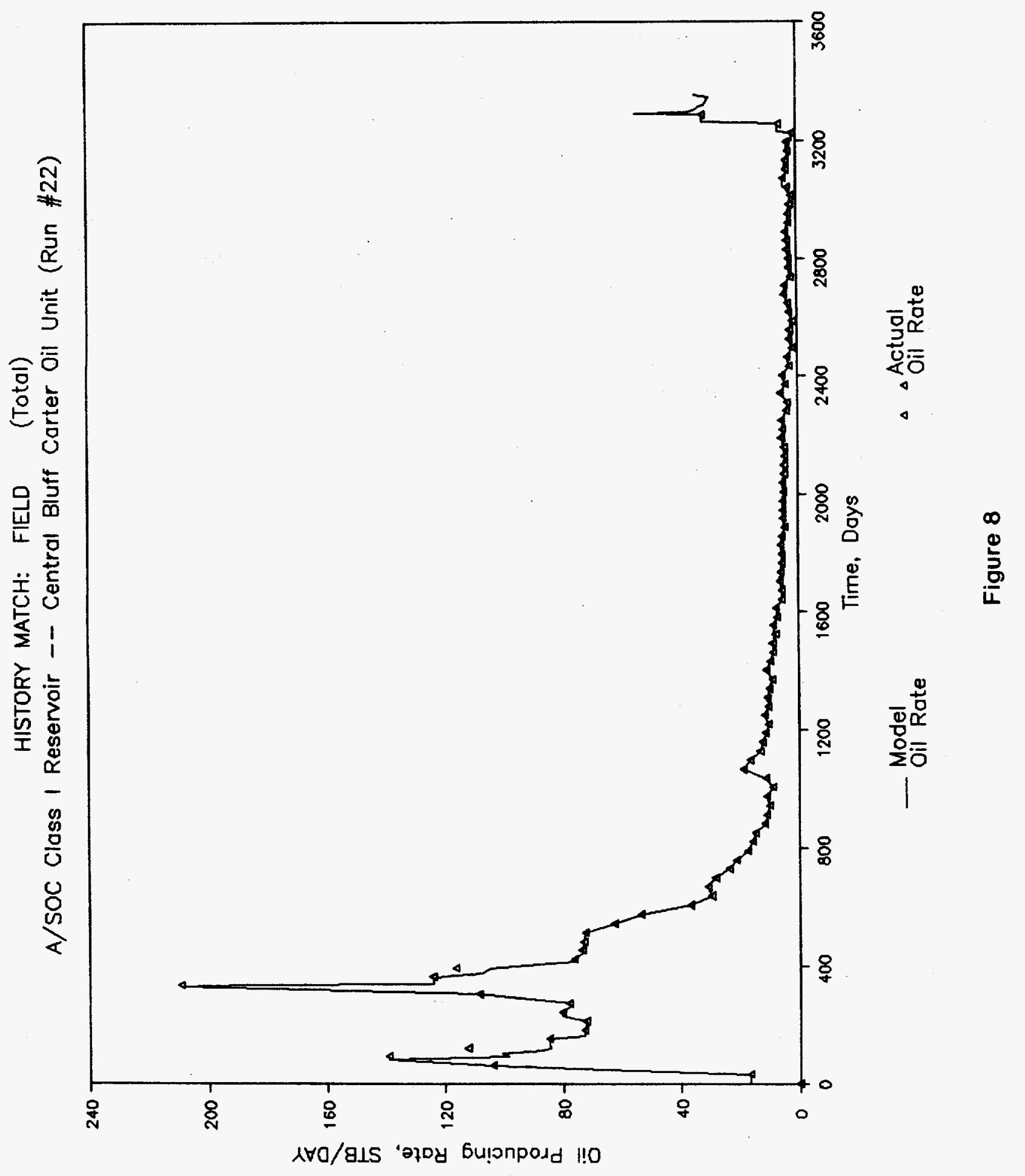




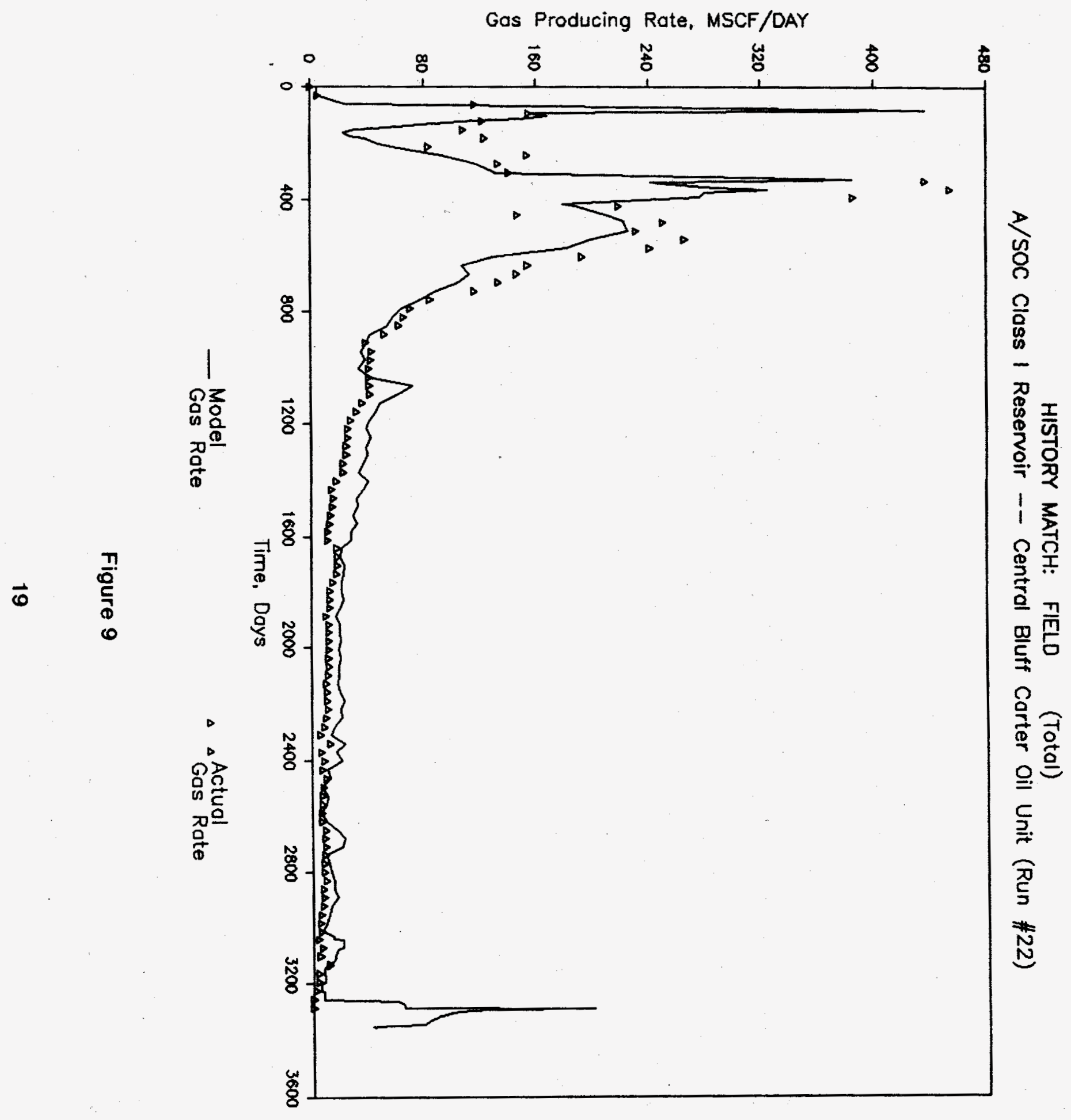


HISTORY MATCH: FIELD (Total)

A/SOC Class I Reservoir -- Central Bluff Carter Oil Unit (Run \#22)

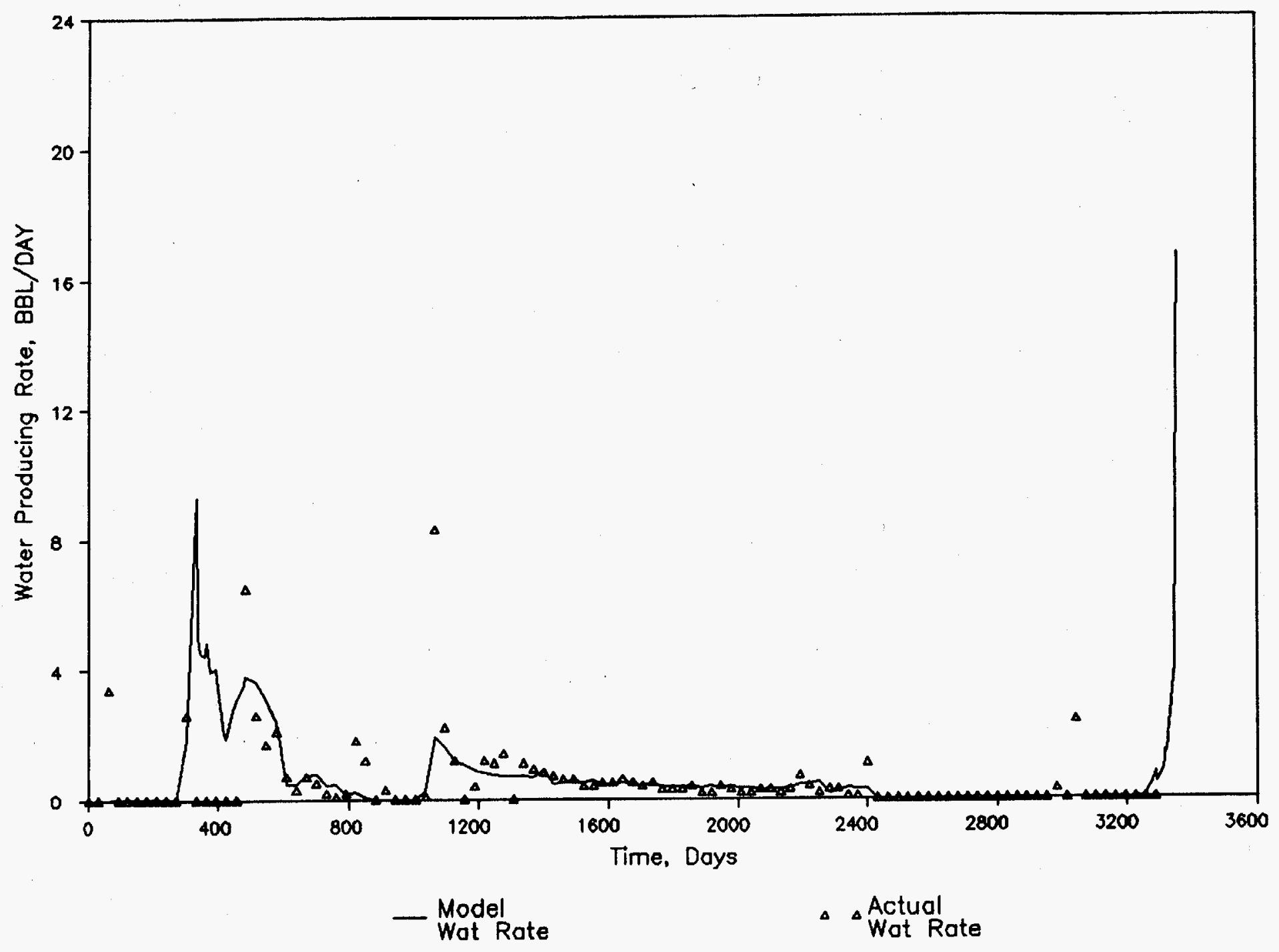

Figure 10 


\section{b. North Fairview Unit}

Field Operations Performed. Unitization was approved on May 1, 1993. A chronology of field operations since that time is shown in Table 3. In May; the Bowman 33-5 \#1 (previously abandoned producer) was re-entered and prepared for conversion to a water injection well. Casing was tested for mechanical integrity, a radioactive tracer $\log$ run, the well location was restored and cleaned, and concrete slabs poured for the water injection equipment.

\begin{tabular}{|c|l|}
\hline \multicolumn{1}{|c|}{$\begin{array}{c}\text { Table 3 } \\
\text { North Fairview Carter Oil Unit } \\
\text { Chronology of Events }\end{array}$} \\
\hline Date & \multicolumn{1}{|c|}{ Description } \\
\hline $05 / 01 / 93$ & Unit approved \\
\hline $05 / 03 / 93$ & Survey Bowman location \\
\hline $05 / 12 / 93$ & Start re-entry of Bowman 33-5 \\
\hline $05 / 17 / 93$ & Finish re-entry \\
\hline $05 / 19 / 93$ & Run radioactive tracer log \\
\hline $05 / 19 / 93$ & Mechanical integrity test of casing \\
\hline $05 / 26-27 / 93$ & Restore and clean location \\
\hline $05 / 26-27 / 93$ & Pour concrete slabs \\
\hline $06 / 01 / 93$ & Begin construction of water injection equipment \\
\hline $06 / 02 / 93$ & Set two 400 bbl tanks \\
\hline $06 / 07 / 93$ & Tied tanks together, hung stairway and landing \\
\hline $06 / 10 / 93$ & Drilling water source well and hook up electrical \\
\hline $06 / 16 / 93$ & Received approval from State O\&G Board to start injection \\
\hline $06 / 17 / 93$ & Casing water well \\
\hline $06 / 23 / 93$ & Install water pump and fill tanks \\
\hline $06 / 26 / 93$ & Start water injection \\
\hline $06 / 26 / 83$ & Monitor waterflood \\
\hline & \\
\hline 0
\end{tabular}


Waterflood Results. Water injection into the Bowman 33-5 \#1 was initiated on June 26, 1993. A summary of the waterflood operations is given in Table 4 and Figure 11. Pressure at the injection well was realized about one month after injection commenced (Figure 12). Five hundred gallons of xylene were injected into the Bowman 33-5 \#1 in an attempt to lower the injection pressure. The pressure remained the same. A subsequent acid job was performed to mediate any damage from the plugging and abandonment operation. A slight decrease in pressure was observed, but soon returned to previous levels.

During the September - May 1994 period, water injection rates at the Bowman 335 \#1 well have been maintained between 200-250 BPD with a gradual increase in injection pressure from $1240 \mathrm{psi}$ to $1400 \mathrm{psi}$. Oil production rates from the three producing wells have remained at about 3 STBD for the Smith 33-6, 3 STBD for the Perkins 33-11, and 1 STBD for the Perkins Young 33-10 well (Figures 13-15). Unit water production remains at zero* (Table 4), indicating possible formation of an oil bank.

* (36 BW reported in June 1993 is BS\&W from tank bottoms.) 


\section{NORTH FAIRVIEW CARTER OIL UNIT Monthly OperationsReport}

UNITIZED 5/1/93

\begin{tabular}{|c|c|c|c|c|c|c|c|c|c|c|c|c|c|}
\hline & MAY 93 & JUNE & $\underline{\text { JULY }}$ & $\underline{A \cup G}$ & SEP & OCT & NOV & DEC & JAN 94 & FEB & MAR & APR & MAY \\
\hline Days On & 31 & 23 & 31 & 27 & 29 & 31 & 30 & 31 & 29 & 28 & 31 & 30 & 31 \\
\hline Monthly Oil Production & 160 & 157 & 145 & 134 & 189 & 153 & 131 & 142 & 243 & 205 & 166 & 166 & 187 \\
\hline Dally Avg Oil Production & 5 & 7 & 5 & 5 & 7 & 5 & 4 & 5 & 8 & 7 & 5 & 6 & 8 \\
\hline Cum. Oil Production & 104,555 & 104,712 & 104,857 & 104,991 & 105,180 & 105,333 & 105,464 & 105,606 & 105,849 & 106,054 & 106,220 & 106,386 & 106,573 \\
\hline Cum. Oll Prod, since Unit & 160 & 317 & 462 & 596 & 785 & 938 & 1,069 & 1211 & 1454 & 1,659 & 1,825 & 1,091 & 2,178 \\
\hline Monthly Water Production & 0 & 36 & 0 & 0 & 0 & 0 & 0 & 0 & 0 & 0 & 0 & 0 & 0 \\
\hline Dally Avg Water Production & 0 & 2 & 0 & 0 & 0 & 0 & 0 & 0 & 0 & 0 & 0 & 0 & 0 \\
\hline Cum. Water Production & 732 & 768 & 768 & 768 & 768 & 768 & 768 & 768 & 768 & 768 & 768 & 768 & 768 \\
\hline Cum. Water Prod since Unit & 0 & 36 & 36 & 36 & 36 & 36 & 36 & 36 & 36 & 36 & 36 & 36 & 36 \\
\hline Monthly Water Injection & 0 & 450 & 2,250 & 5,050 & 5,900 & 6,250 & 6,225 & 5,300 & 4,125 & 6,150 & 7,550 & 7,350 & 7.325 \\
\hline Dally Avg. Water Injection & 0 & 20 & 73 & 187 & 203 & 202 & 208 & 171 & 142 & 220 & 244 & 245 & 236 \\
\hline Avg. pressure (psia) & 0 & 0 & 0 & 843 & 1,214 & 1,281 & 1,303 & 1,246 & 909 & 1,192 & 1,399 & 1,400 & 1,400 \\
\hline Cum Water Inj since Unit & 0 & 450 & 2,700 & 7,750 & 13,650 & 19,900 & 26,125 & 31425 & 35,550 & 41700 & 49,250 & 56.600 & 63,925 \\
\hline Producing Wells & 3 & 3 & 3 & 3 & 3 & 3 & 3 & 3 & 3 & 3 & 3 & 3 & 3 \\
\hline Inective Wolls & 0 & 0 & 0 & 0 & 0 & 0 & 0 & 0 & 0 & 0 & 0 & 0 & 0 \\
\hline Injection Wells & 0 & 1 & 1 & 1. & 1 & 1 & 1 & 1 & 1 & 1 & 0 & 0 & 0 \\
\hline Water Sounce Wells & 0 & 1 & 1 & 1 & 1 & 1 & 1 & 1 & 1 & 8 & 0 & 0 & 0 \\
\hline
\end{tabular}


NORTH FAIRVIEW CARTER OIL UNIT

Oil Production

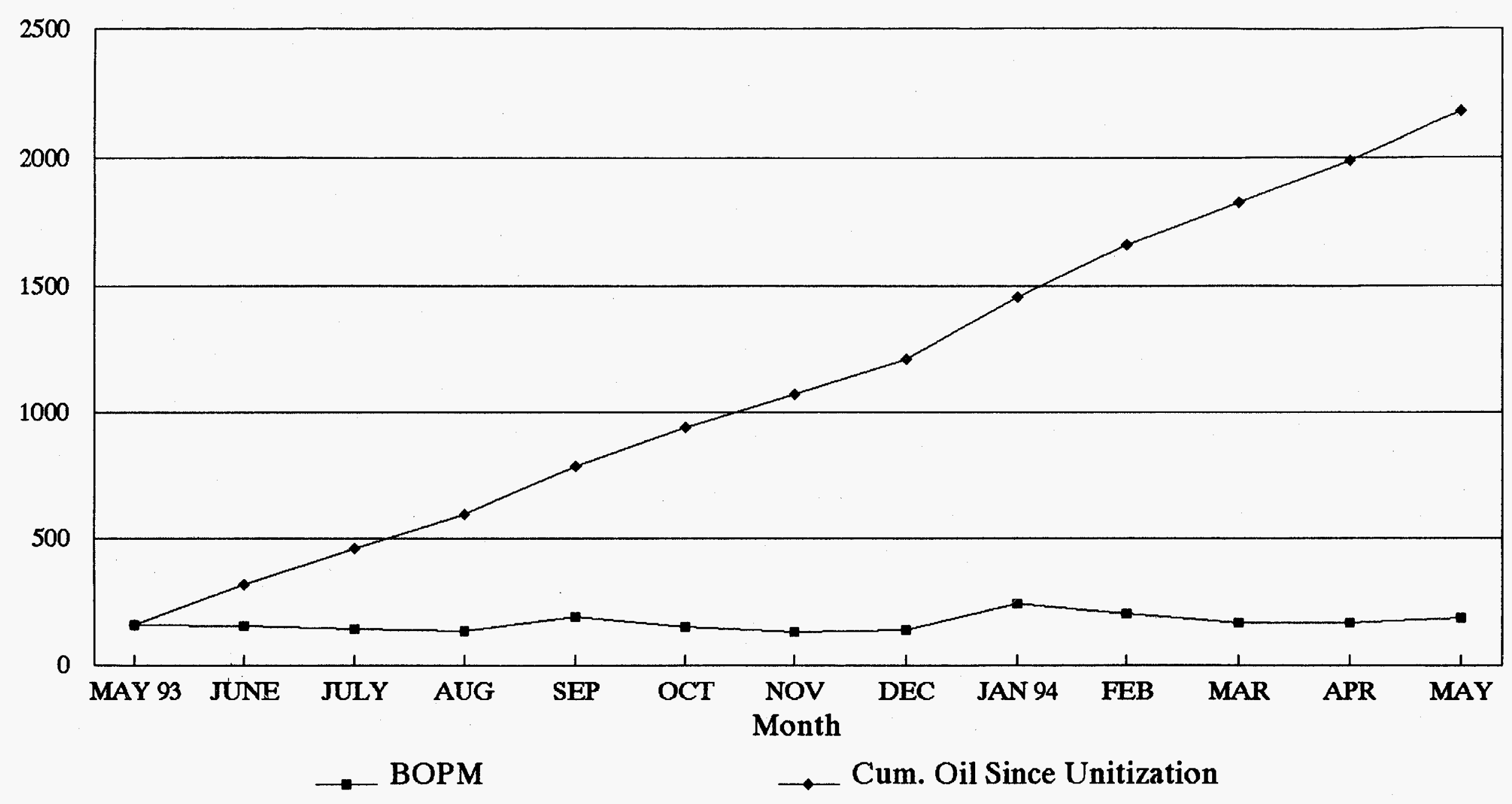

Figure 11 
NORTH FAIRVIEW CARTER OIL UNIT

Water Injection

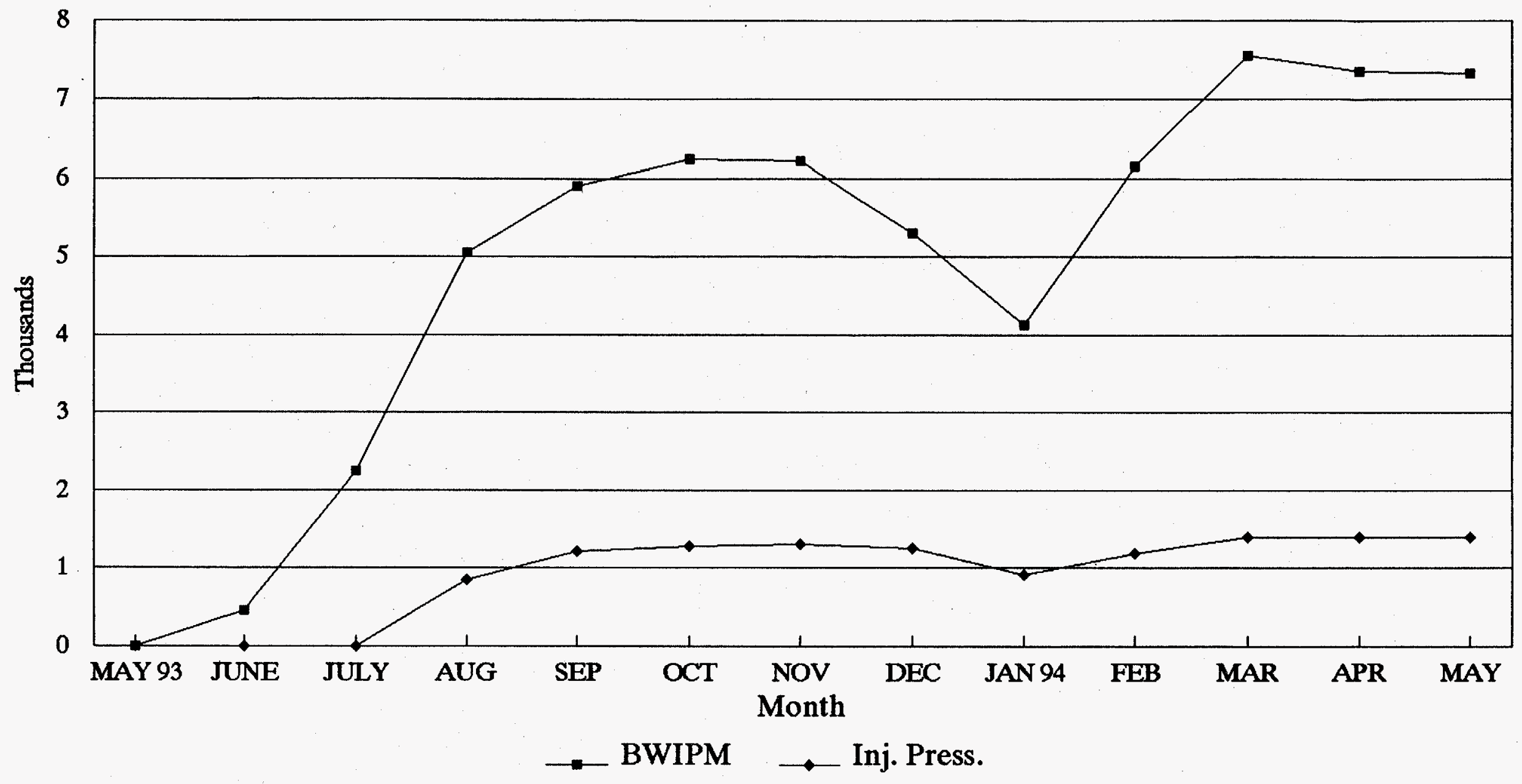

Figure 12 


\section{Figure 13 \\ SMITH 33-6 \\ OIL PRODUCTION}

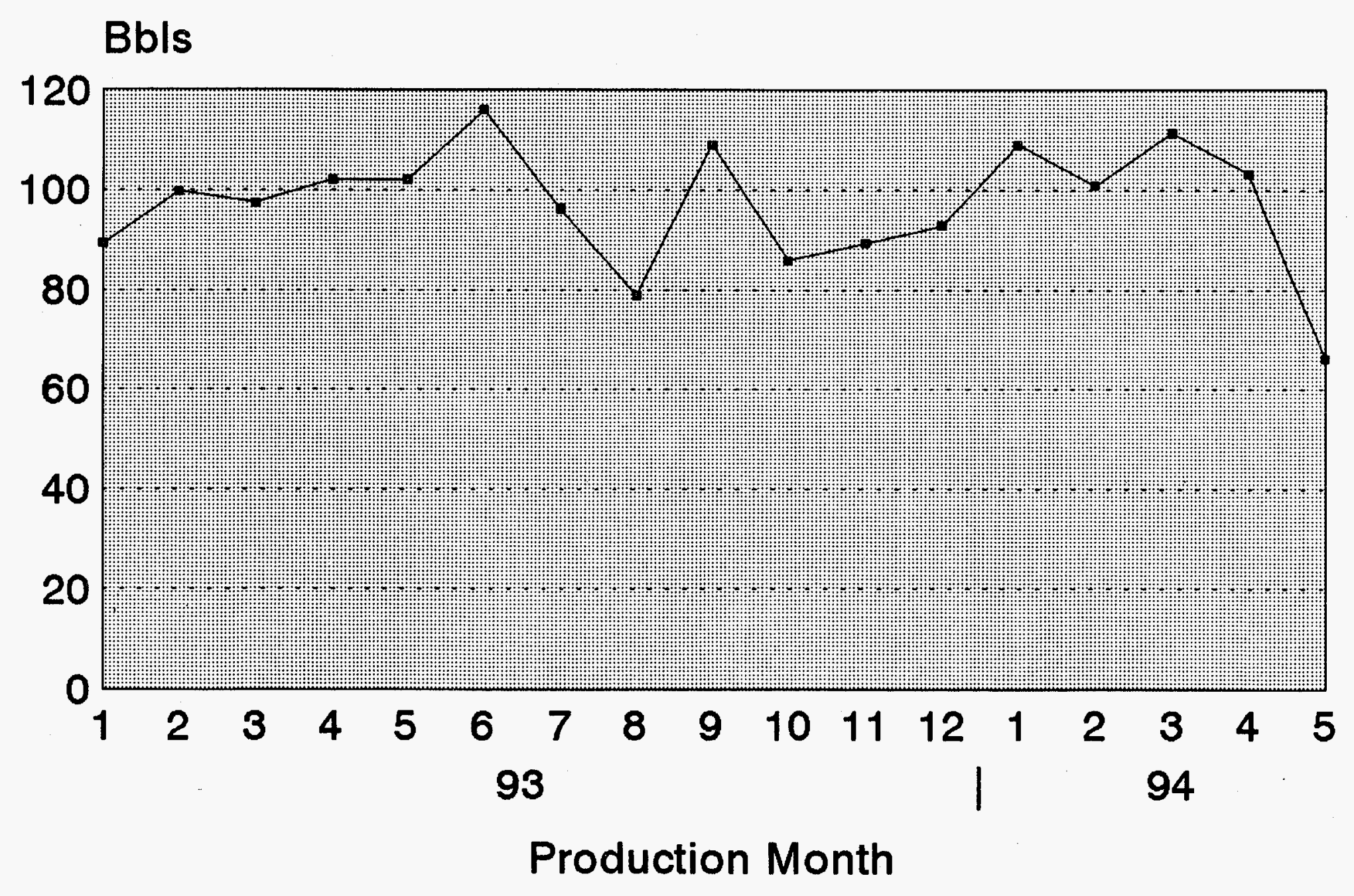

NORTH FAIRVIEW CARTER OIL UNIT 
Figure 14

\section{PERKINS 33-11 OIL PRODUCTION}

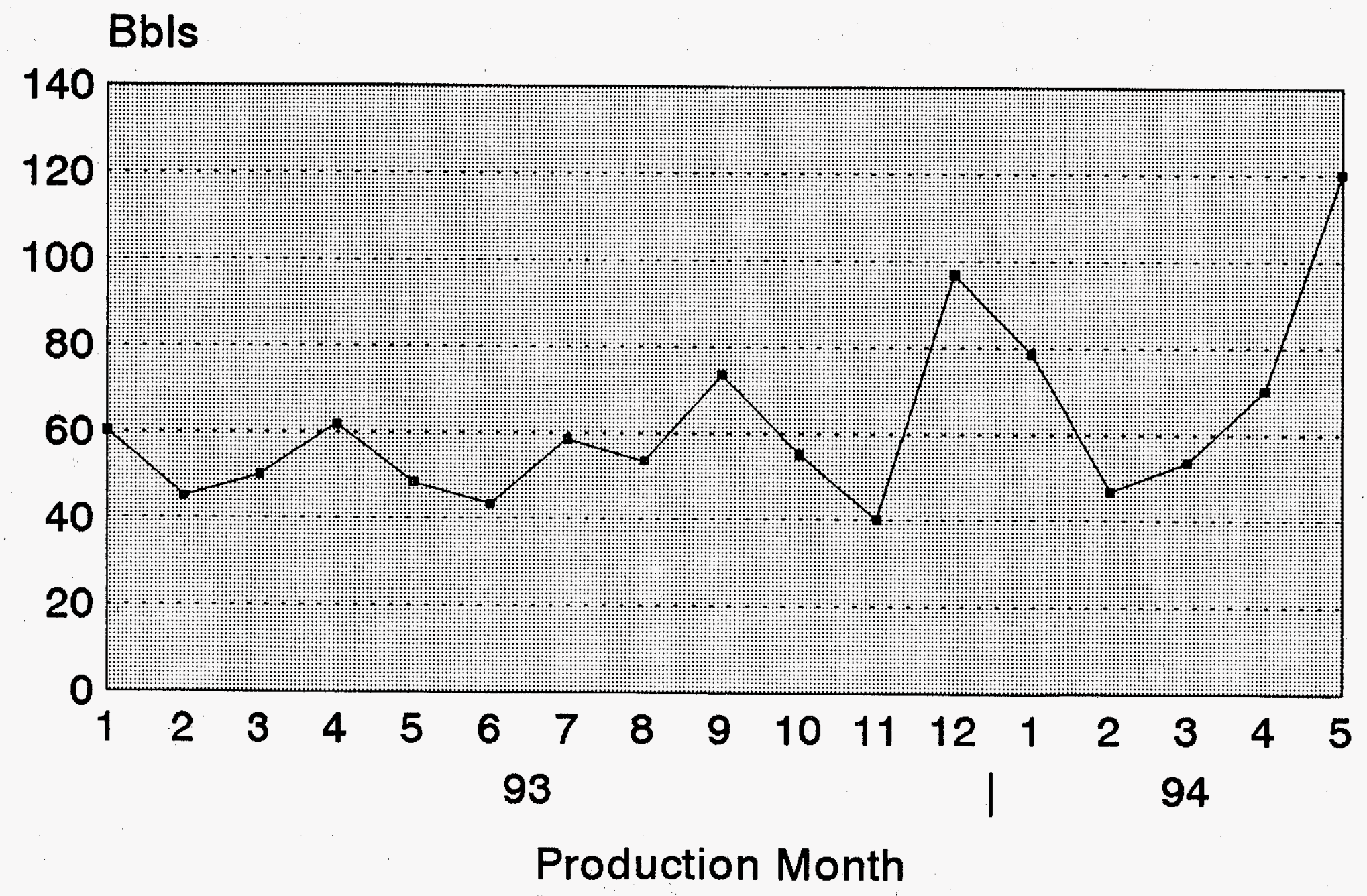

NORTH FAIRVIEW CARTER OIL UNIT 


\section{PERKINS YOUNG 33-10 OIL PRODUCTION}

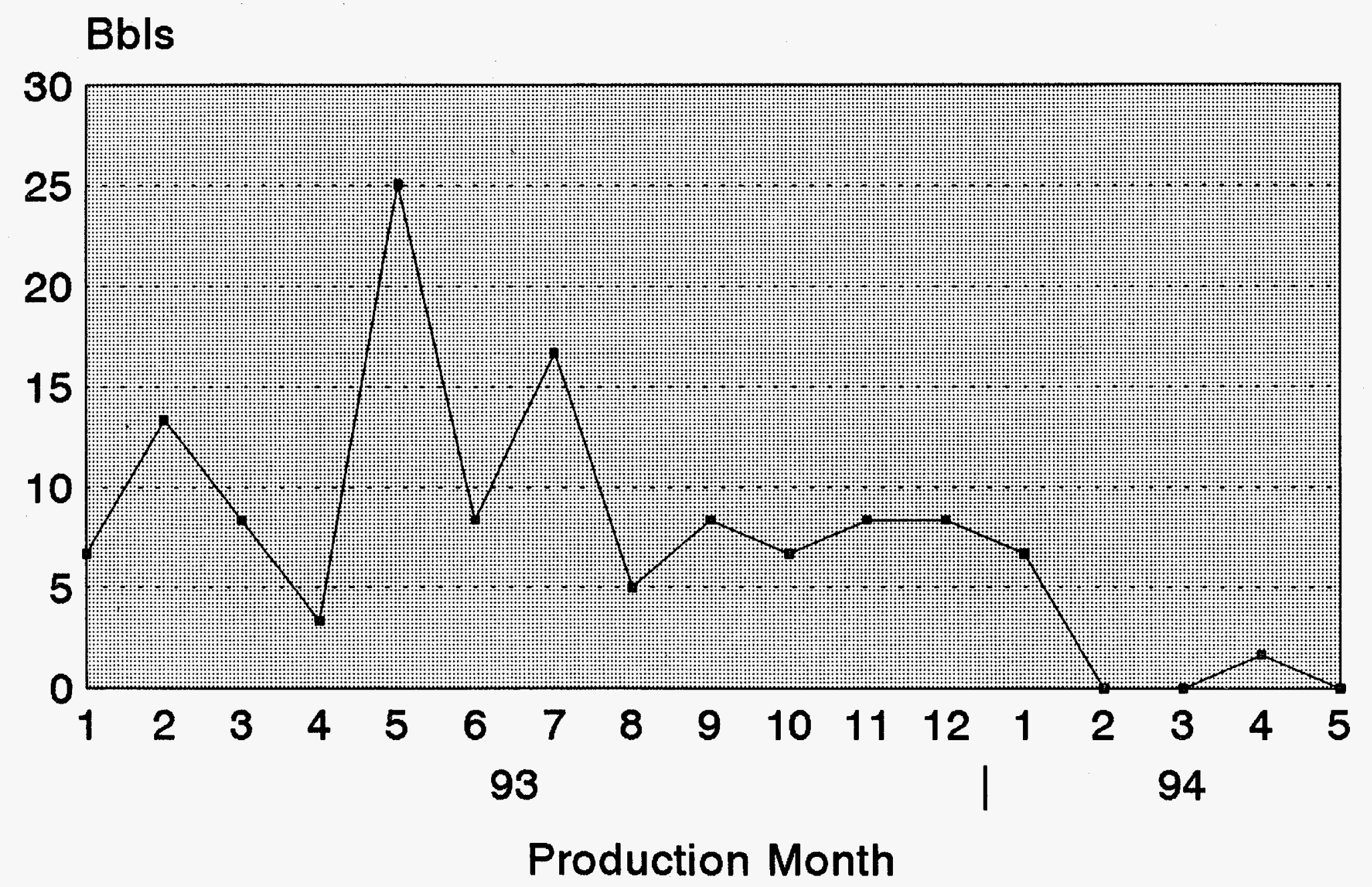

NORTH FAIRVIEW CARTER OIL UNIT 
In May 1994, all three producing wells were worked over. All pumps were changed out and lowered to ensure pump-off and maximize current production levels in anticipation of waterflood response.

To date 63,925 BW have been injected into the Bowman 33-5 WW with no production response. Calculated fillup for the reservoir is estimated at $93,500 \mathrm{BW}$, indicating anticipated flood response to be months away. Monitoring of the field continues and operations will remain the same.

Reservoir Modeling. A simulation study to characterize the Carter sandstone at the North Fairview Unit was performed by Advanced Resources. This characterization was achieved by adjusting key reservoir properties (such as porosity, absolute permeability, and three-phase relative permeability relationships) to match actual well performance for the unit. Using the ROAST II simulator, good matches were obtained for the production rates and limited pressure histories for the three producing wells (Smith 33-6, Perkins Young 33-10 and Perkins 33-11) and the injection well (Bowman 335 \#1) for a production period in excess of 11 years (July 1982 through August 1993). (Figures $16 \& 17$ )

A $24 \times 16 \times 1$ simulation grid was constructed in such a way as to easily alter (enlarge or reduce) the reservoir's no-flow boundaries if it became apparent during the history match that the reservoir pore volume required further adjustment. Based on the history match results thus far, the reservoir boundaries and thickness variations appear to have been well defined during Anderman/Smith's geologic evaluation. With the reservoir geometry determined for the North Fairview area, values of reservoir porosity between 10 and $19 \%$ were used in the history match of well performance. Using the net thickness values digitized from the isopach map (thicknesses with $10 \%$ porosity or more), the initial fluids-in-place calculated by the simulator are in excess of 900 MSTB of oil and nearly 400 MMscf of solution gas. 
The total oil and gas producing rates for all wells in the unit are shown in Figures 16 and 17. (Time zero on these figures is July 31, 1982). Good agreement between simulated and observed production rates was achieved with the reservoir characterization determined from the history match. The total oil producing rate (Figure 16) peaked at about 160 STBD during the second year of production from the field (representing production from four wells), with a subsequent decline to less than 40 STBD by the end of the fourth year. For the last five years, the total oil production rate from the unit has been less than 10 STBD from the three remaining producing wells (Bowman 33-5 \#1 was shut-in about 4.5 years into field life).

During this same 11-year production period, the total gas rate (Figure 17) from the North Fairview wells peaked at 200 to 250 MCFD and has shown a relatively steady decline (to less than $50 \mathrm{MCFD}$ ) with primary depletion of the reservoir. Essentially no water production has occurred from the unit; total water production is reported as less than $750 \mathrm{bbl}$ for the 11-year period.

For the reservoir permeabilities used in the simulator $(20-85 \mathrm{md})$, the decline in both oil and gas production from the North Faiview wells corresponds to a reduction in average reservoir pressure from 1,000 psi to $150 \mathrm{psi}$ at the end of the 11-year period. With reservoir energy nearly depleted, waterflood operations for the unit were initiated in June 1993 with water injection at the Bowman 33-5 \#1 well. Since that time, in excess of $25 \mathrm{Mbbls}$ of water have been injected with no measurable change in either reservoir pressure or the production rates from the three producing wells. This lack of reservoir response to water injection at the Bowman 33-5 \#1 provided a valuable check on the simulation results which also show a lack of change in either reservoir pressure or production rates for this volume of injected water. 


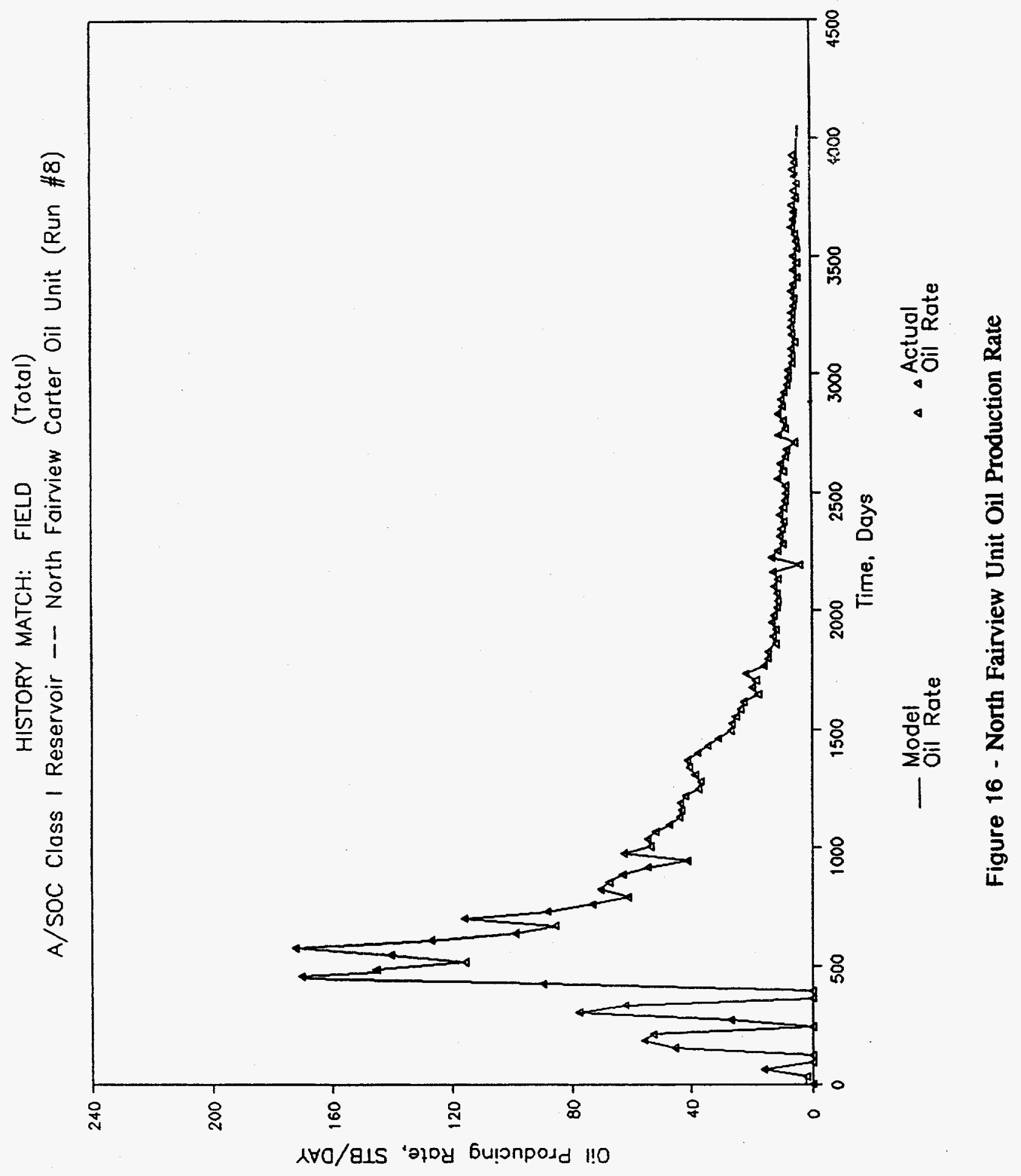


HISTORY MATCH: FIELD (Totol)

A/SOC Closs 1 Reservoir -- North Fairview Carter Oil Unit (Run \#8)

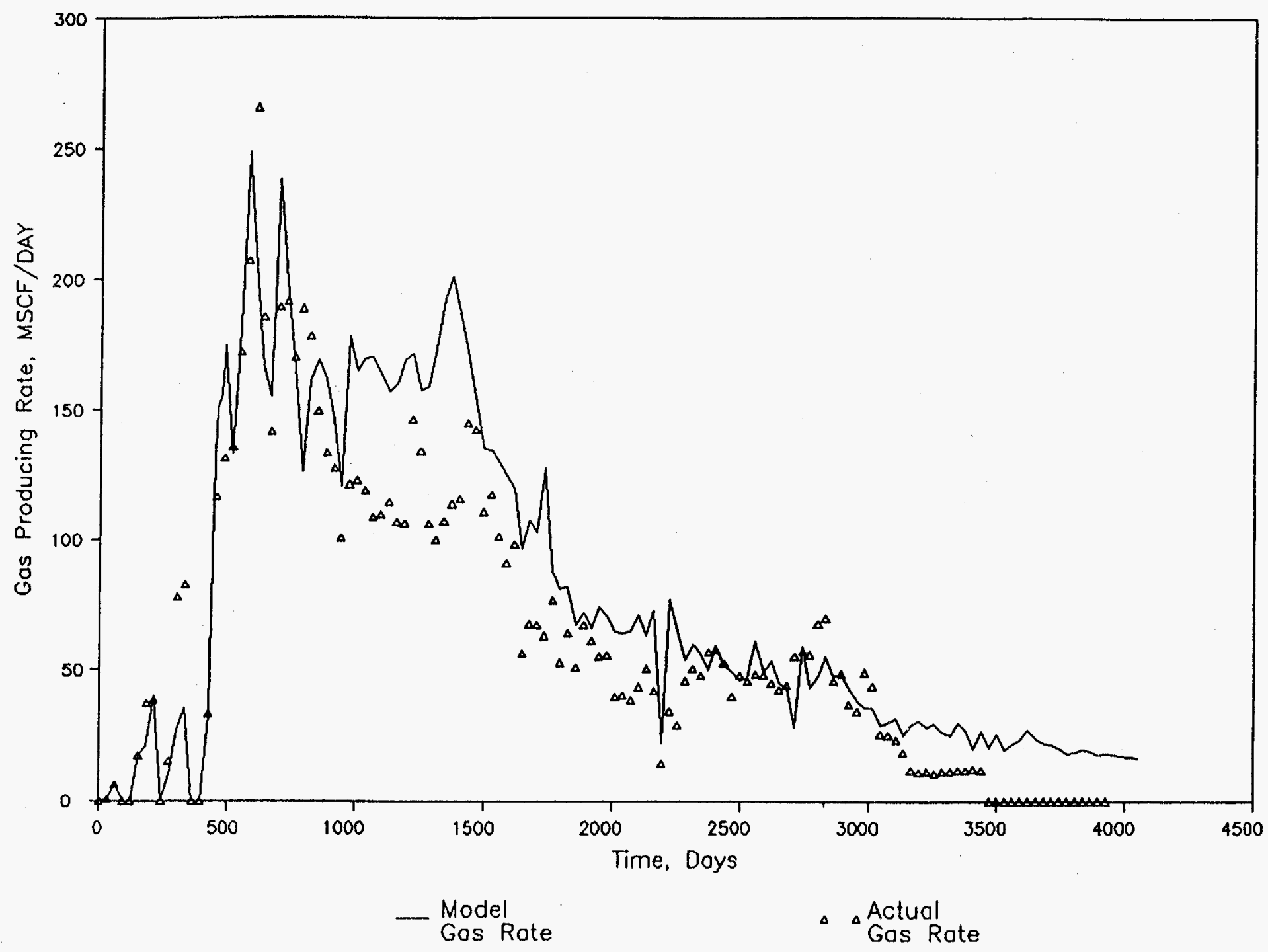

Figure 17 - North Fairview Unit Gas Production Rate 